\title{
SEX VARIATIONS IN THUMBPRINT RIDGE COUNT OF A NIGERIAN POPULATION IN CALABAR MUNICIPALITY
}

ISO ISO USANG ${ }^{1}$, MESEMBE OE${ }^{1}$, EWUNONU EO² .

${ }^{1}$ Department of Human Anatomy, Faculty of Basic Medical Sciences, College of Medical Sciences, University of Calabar, PMB 1115, Calabar, Cross River State, Nigeria.

${ }^{2}$ Department of Anatomy, Faculty of Basic Medical Sciences, Ebonyi State University, PMB 0053, Abakaliki, Ebonyi State, Nigeria.

Correspondence to Mr. Iso, Iso Usang Phone Number +234803 245 3465, email: usangiso@gmail.com

\begin{abstract}
The present study aimed at determining the association between thumbprint ridge count and sex variation among Nigerians in Calabar Municipality. A total number of 300 subjects (150 males and 150 females) aged between 12-35 years participated in the study. Conventional method of using ink pad was used to collect thumbprint of both hands and analysed using magnifying lens. The study confirmed the results of some earlier works done by other researchers on fingerprints. It further established the distribution proportions of thumbprint for both hands in both sexes for the population. The uniqueness of fingerprint to individuals was reaffirmed as no two thumbprints were identical among the 300 subjects under study. These results show that the order of prevalence are as follows; among males, in whatever combination of thumbprint pattern, whorl is the most occurring, followed by loop and arch. Among females, in whatever combination of thumbprint pattern, loop is the most occurring followed by whorl and arch. The result equally showed the mean thumbprint ridge count of females to be lower than that of males (20.91 as against 27.85 respectively). The difference in pattern between left and right hands in females was significant. In conclusion the thumbprint ridge count shows gender dysmorphism in the Nigerian population.
\end{abstract}

Keywords: Fingers, epidermal ridges, thumbprint ridge count

\section{INTRODUCTION}

The fingers of humans possess series of friction ridge skin consisting of a series of furrows and ridges generally referred to as - fingerprints. Fingerprint constitutes a significant biometric variable that have been used in many biometric utilities such as in human biology, morphology, anthropology and in genetics. Their role especially in the field of forensics have become applicable and indispensable based on their reliability and validity of features, easy classification and uniqueness. In determination of identity, adequate and reliable knowledge of sex with certainty reduces the process of identification by $60 \%$ (Adamu, 2016) using fingerprint ridge counts and density.

This is possible based on the assumption that the ridge counts, and features remain intact. However, variations in ridge dimensions and sex differences in ridge breadth have been reported (Manish et al, 2008; Prateek et al, 2009; Ritu 2012; Rijo, 2013; Mulawka, 2014). Ridges and their patterns exhibit a number of properties that reflect the genetic makeup of individuals.

The uniqueness of a person's fingerprints gave rise to dermatoglyhics and this is because dermatoglyphics is the reflection of DNA and hence, does not change. Fingerprints persist lifelong unless damage to the dermis occurs. Interestingly, as creases develop on the brain during development, they are reflected on the prints (Lakshmi et al, 2014) representing the various regions of the brain. These creases or dermal ridges often appear in the third to fifth month of neonatal life and they never change. As such, one can say that dermatoglyphic abnormalities are as a result of genetic or any other factor that expresses itself before the fifth month of neonatal life (Mellor, 1992).

The science of fingerprint has been used generally for the identification or verification of people and for official documentation. Based on the varieties of the information available from the fingerprint its identity can be processed along with gender, age 
and ethnicity. As such a host of empirical verifications have been studied and analysed even in Nigeria; however, little or nothing has been done as regards thumbprint ridge analysis. Research concerning thumbprint ridge counts and fingerprints are few in the Nigerian population. Also, the need for a fingerprint database for all individuals within a locality always arises during civil litigations and criminal cases. If this research proves beyond doubt that thumbprint ridge count is influenced by gender, it would be most useful in documentation, matching and database build up as well as reconstruction of thumbprints for criminal investigation and forensic science as the case may be.

\section{METHODOLOGY}

A total of three hundred (300) subjects were used for this study. These subjects were all Nigerians residing in Calabar Municipality in a ratio of 50 males to 50 females, making a total of 150 males and 150 females for the research. The subjects were within the age bracket of 12-35 years of age. In order to take the fingerprints of the subjects, the following materials were used: Ink pad, Magnifying lens, White sheet of paper, Hand gloves, Methylated spirit, and Non-sterile cotton wool. Subjects included were Nigerians resident in Calabar Municipality and those whose thumbs were free of inflammation, deformation or pathological changes while subjects without fingers or those who were having inflammatory or pathological changes on their thumbs were excluded. Thumbprints were collected by pressing the thumbs on ink pad with moderate pressure and afterwards, pressing into a white plane sheet.
Samples with interrupted ridges were discarded and repeated. To ensure uninterrupted ridges and prints, the subjects' thumbs were wiped with nonsterile cotton wool dipped in methylated spirit. A magnifying lens with the magnification (x10) was used to trace the thumbprints. This is to enlarge the tiny ridges and make them more prominent and easily accessible to the naked eye. In the analysis of these prints, Henry system of classification was adopted.

The collected data were coded and entered in Microsoft Excel 2010 and statistically analysed using Statistical Package for Social Sciences (SPSS) 20.0. Specifically, Chi-square test and student's ttest was used to test for association between the variables. Level of significance was considered at $\mathrm{p}<0.05$.

\section{RESULTS}

The most predominant thumbprints pattern was loop $-46.7 \%$, followed by whorl $-40.0 \%$ and arch $13.3 \%)$. In. the left hand of males, the most predominant thumbprints pattern was Whorl $50.0 \%$, followed by loop $-38.0 \%$ and arch $12.0 \%)$. In the right hand of females, the most predominant thumbprints pattern was loop $45.3 \%$, followed by whorl $-36.0 \%$ and arch $18.7 \%)$. While in the left hand of females the most predominant thumbprints pattern was loop $49.3 \%$, followed by whorl $-36.7 \%$ and arch $-14.0 \%$ (Table 1). Females have lower thumbprint ridge count mean values compare to males (Table 2 and 3).

In both left and right combinations, males have more whorl (75) followed by loop (57) and arch (18) [Table 4]. In table 4 Significant differences, as indicated by $\mathrm{P}<0.05$, were found between the thumbprint pattern of both hands.

In both left and right combinations, females have more loop (74) followed by whorl (55) and arch (21) [Table 5]. In table 5 significant differences, as indicated by $P<0.05$, were found between the thumbprint pattern of both hands in females.

In the right hand of both sexes, loop (68) is the predominant thumbprint pattern followed by whorl (54) and arch (28) [Table 6]. In table 6 no significant difference, as indicated by $\mathrm{P}<0.05$, were found in the right thumbprint pattern of both sexes. In the left hand of both sexes, loop (74) is the most predominant thumbprint pattern followed by whorl (55) and arch (21) (Table 7). In table 7 
no significant difference, as indicated by $\mathrm{P}<0.05$, were found in the left thumbprint pattern of both

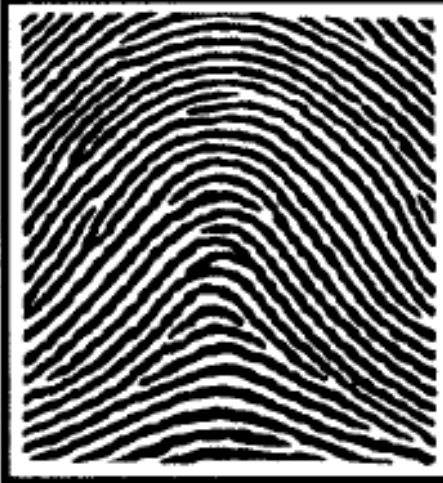

A

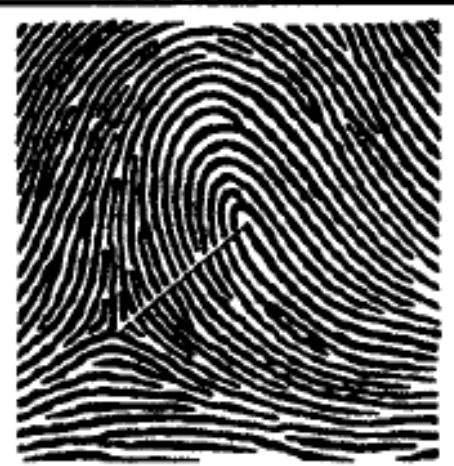

B

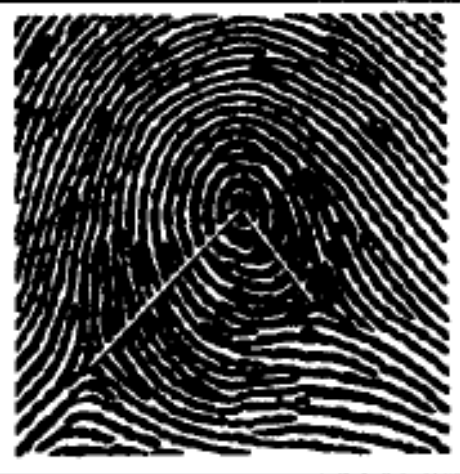

C

sexes.

Figure 1: Examples of fingertip patterns representing an arch (panel A), loop (panel B), and whorl (panel C). Adapted from Holt (1961). The following ridge-counting protocol was used: ridge count $=$ (ridges crossing the longer line $)+(1 / 2$ of ridges crossing the shorter line); therefore, the ridge-count values in these examples are $\mathrm{A}=0, \mathrm{~B}=13$, and $\mathrm{C}=21$ (i.e., $17+(0.5 \times 8)$ ).

Table 1: Respondents' thumbprint patterns

\begin{tabular}{|c|c|c|c|}
\hline Variable & Group & Frequency & Percent \\
\hline \multirow{4}{*}{ Male Right Thumbprint pattern } & Arch & 20 & 13.3 \\
\cline { 2 - 4 } & Loop & 70 & 46.7 \\
\cline { 2 - 4 } & Whorl & 60 & 40.0 \\
\cline { 2 - 4 } & Total & $\mathbf{1 5 0}$ & $\mathbf{1 0 0 . 0}$ \\
\hline \multirow{4}{*}{ Male Left Thumbprint pattern } & Arch & 18 & 12.0 \\
\cline { 2 - 4 } & Loop & 57 & 38.0 \\
\cline { 2 - 4 } & Whorl & 75 & 50.0 \\
\cline { 2 - 4 } & Total & $\mathbf{1 5 0}$ & $\mathbf{1 0 0 . 0}$ \\
\hline \multirow{4}{*}{ Female Right Thumbprint pattern } & Arch & 28 & 18.7 \\
\cline { 2 - 4 } & Loop & 68 & 45.3 \\
\cline { 2 - 4 } & Whorl & 54 & 36.0 \\
\cline { 2 - 4 } & Total & $\mathbf{1 5 0}$ & $\mathbf{1 0 0 . 0}$ \\
\hline \multirow{5}{*}{ Female Right Thumbprint pattern } & Arch & 21 & 14.0 \\
\cline { 2 - 4 } & Loop & 74 & 49.3 \\
\cline { 2 - 4 } & Whorl & 55 & 36.7 \\
\cline { 2 - 4 } & Total & $\mathbf{1 5 0}$ & $\mathbf{1 0 0 . 0}$ \\
\hline
\end{tabular}

Table 2: Descriptive Statistics of thumbprint ridge count

\begin{tabular}{|c|c|c|}
\hline & $\mathrm{N}$ & Mean SD \\
\hline Thumbprint Ridge Count (Male) & 150 & 27.8514 .862 \\
\hline Thumbprint Ridge Count (Female) & 150 & 20.9113 .401 \\
\hline
\end{tabular}



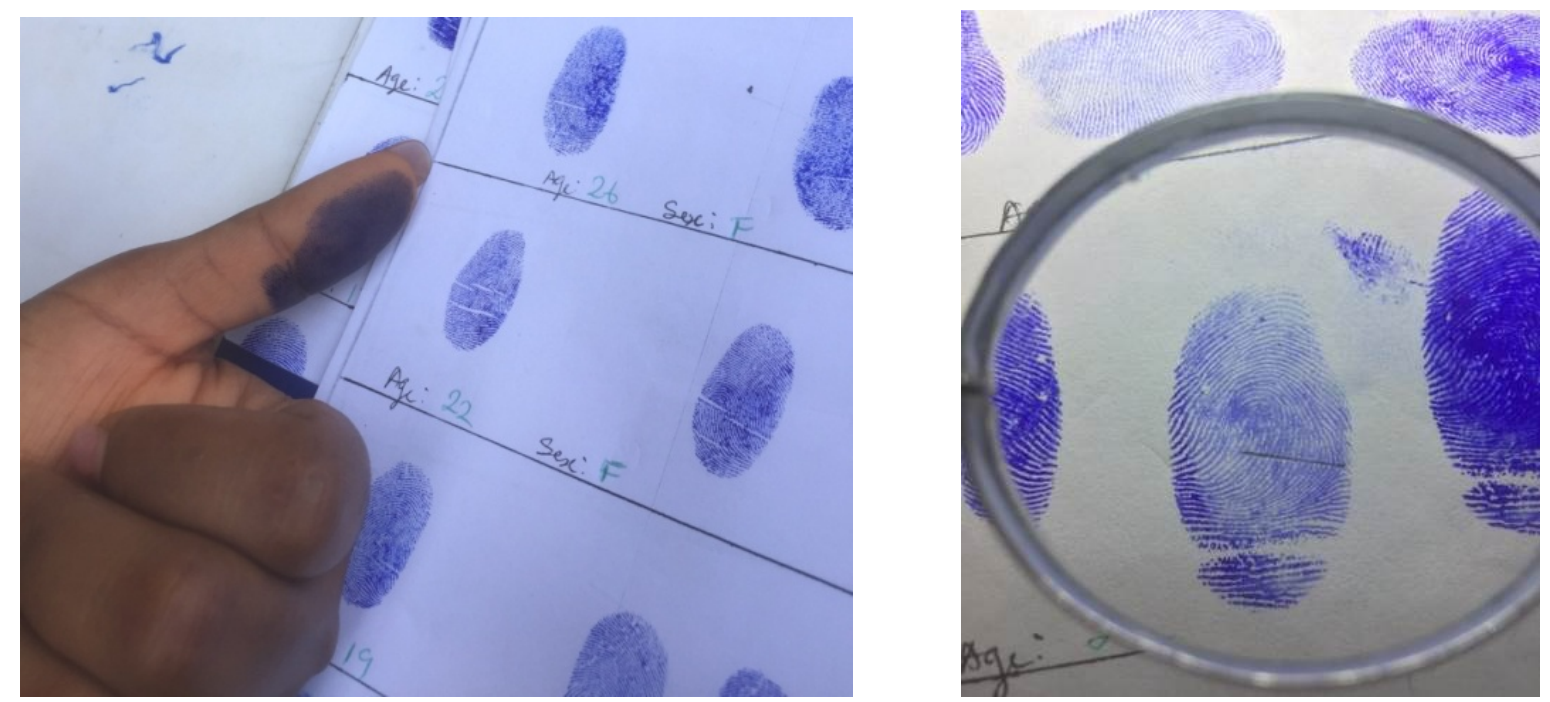

Figure 2: Diagram showing sample collection and thumbprint ridge analysis using magnifying lens

Table 3: One-sample T-test of thumbprint ridge count in both sexes

\begin{tabular}{|l|c|c|c|c|c|c|}
\hline \multirow{2}{*}{} & \multicolumn{7}{|l|}{ Test Value $=0$} \\
\cline { 2 - 7 } & \multicolumn{7}{|c|}{$\begin{array}{c}\text { 95\% Confidence Interval } \\
\text { of the Difference }\end{array}$} \\
\cline { 2 - 7 } & $\mathrm{t}$ & $\mathrm{Df}$ & $\begin{array}{c}\text { Sig. (2- } \\
\text { tailed) }\end{array}$ & $\begin{array}{c}\text { Mean } \\
\text { Difference }\end{array}$ & Lower & Upper \\
\hline $\begin{array}{l}\text { Thumbprint Ridge } \\
\text { Count (Male) }\end{array}$ & 22.948 & 149 & .000 & 27.847 & 25.45 & 30.24 \\
\hline $\begin{array}{l}\text { Thumbprint Ridge } \\
\text { Count (Female) }\end{array}$ & 19.113 & 149 & .000 & 20.913 & 18.75 & 23.08 \\
\hline
\end{tabular}

Table 4: Cross tabulation showing the distribution of left and right thumbprint patterns in males

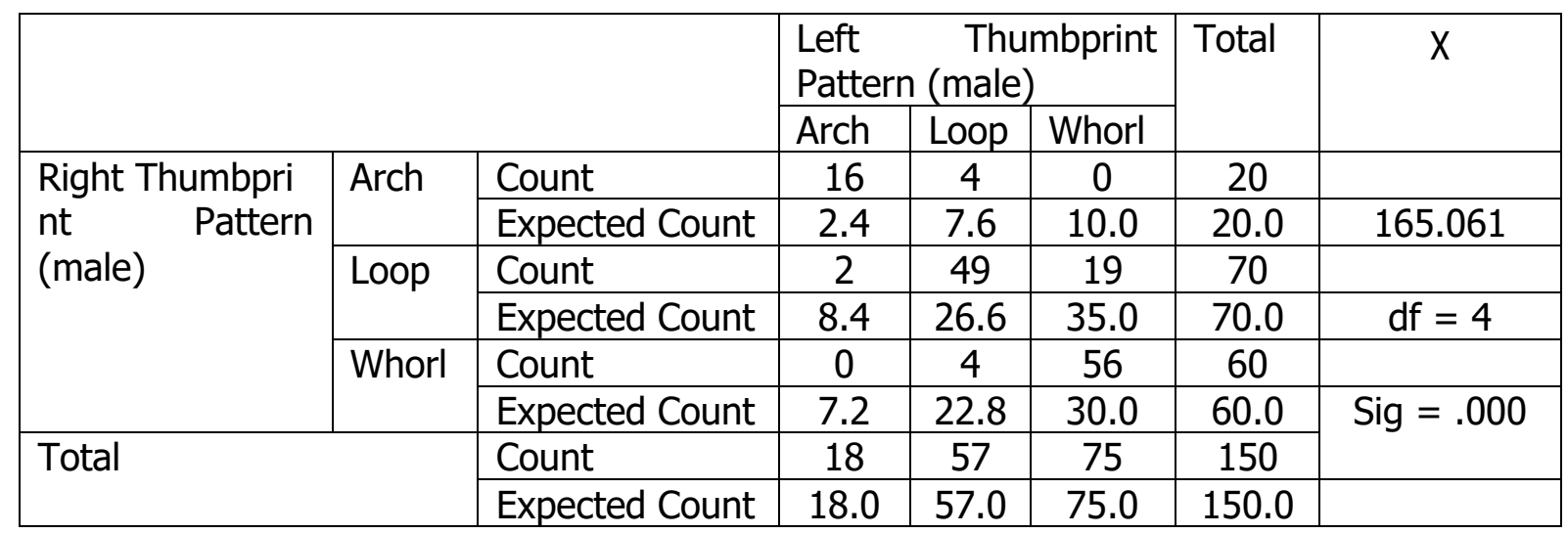


Anatomy Journal of Africa. 2019. Vol 8 (2): 1544 - 1551

Table 5: Crosstabulation showing the distribution of left and right thumbprint patterns in females

\begin{tabular}{|c|c|c|c|c|c|c|c|}
\hline & & & \multicolumn{3}{|c|}{$\begin{array}{l}\text { Left Thumbprint Pattern } \\
\text { (female) }\end{array}$} & \multirow[t]{2}{*}{ Total } & \multirow[t]{2}{*}{$X$} \\
\hline & & & Arch & Loop & Whorl & & \\
\hline \multirow{6}{*}{$\begin{array}{l}\text { Right Thumbpri } \\
\text { nt Pattern } \\
\text { (female) }\end{array}$} & \multirow[t]{2}{*}{ Arch } & Count & 20 & 5 & 3 & 28 & \\
\hline & & $\begin{array}{l}\text { Expected } \\
\text { Count }\end{array}$ & 3.9 & 13.8 & 10.3 & 28.0 & 183.827 \\
\hline & \multirow[t]{2}{*}{ Loop } & Count & 1 & 62 & 5 & 68 & \\
\hline & & $\begin{array}{l}\text { Expected } \\
\text { Count }\end{array}$ & 9.5 & 33.5 & 24.9 & 68.0 & $\mathrm{df}=4$ \\
\hline & \multirow[t]{2}{*}{ Whorl } & Count & 0 & 7 & 47 & 54 & \\
\hline & & $\begin{array}{l}\text { Expected } \\
\text { Count }\end{array}$ & 7.6 & 26.6 & 19.8 & 54.0 & \multirow[t]{2}{*}{ Sig $=.000$} \\
\hline \multirow{2}{*}{\multicolumn{2}{|c|}{ Total }} & Count & 21 & 74 & 55 & 150 & \\
\hline & & $\begin{array}{l}\text { Expected } \\
\text { Count }\end{array}$ & 21.0 & 74.0 & 55.0 & 150.0 & \\
\hline
\end{tabular}

Table 6: Comparison of right thumbprint patterns in males and females

\begin{tabular}{|c|c|c|c|c|c|c|c|}
\hline & \multicolumn{3}{|c|}{$\begin{array}{l}\text { Right Thumbprint Pattern } \\
\text { (female) }\end{array}$} & \multirow[t]{2}{*}{ Total } & \multirow[t]{2}{*}{$X$} \\
\hline & & & Arch & Loop & Whorl & & \\
\hline \multirow{6}{*}{$\begin{array}{l}\text { Right Thumbprin } \\
\text { t Pattern (male) }\end{array}$} & \multirow[t]{2}{*}{ Arch } & Count & 2 & 9 & 9 & 20 & \\
\hline & & $\begin{array}{l}\text { Expected } \\
\text { Count }\end{array}$ & 3.7 & 9.1 & 7.2 & 20.0 & 3.990 \\
\hline & \multirow[t]{2}{*}{ Loop } & Count & 16 & 34 & 20 & 70 & \\
\hline & & $\begin{array}{l}\text { Expected } \\
\text { Count }\end{array}$ & 13.1 & 31.7 & 25.2 & 70.0 & $\mathrm{df}=4$ \\
\hline & \multirow[t]{2}{*}{ Whorl } & Count & 10 & 25 & 25 & 60 & \\
\hline & & $\begin{array}{l}\text { Expected } \\
\text { Count }\end{array}$ & 11.2 & 27.2 & 21.6 & 60.0 & \multirow[t]{2}{*}{ Sig $=.407$} \\
\hline \multirow{2}{*}{\multicolumn{2}{|c|}{ Total }} & Count & 28 & 68 & 54 & 150 & \\
\hline & & $\begin{array}{l}\text { Expected } \\
\text { Count }\end{array}$ & 28.0 & 68.0 & 54.0 & 150.0 & \\
\hline
\end{tabular}

Table 7: Comparison of left thumbprint patterns in males and females

\begin{tabular}{|c|c|c|c|c|c|c|c|}
\hline \multirow{2}{*}{\multicolumn{3}{|c|}{ 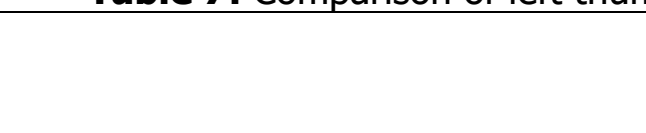 }} & \multicolumn{3}{|c|}{ Left Thumbprint Pattern (female) } & \multirow[t]{2}{*}{ Total } & \multirow[t]{2}{*}{$X$} \\
\hline & & & Arch & Loop & Whorl & & \\
\hline \multirow{6}{*}{$\begin{array}{l}\text { Left Thumbprin } \\
\text { t Pattern (male) }\end{array}$} & \multirow[t]{2}{*}{ Arch } & Count & 0 & 11 & 7 & 18 & \\
\hline & & $\begin{array}{l}\text { Expected } \\
\text { Count }\end{array}$ & 2.5 & 8.9 & 6.6 & 18.0 & 4.943 \\
\hline & \multirow[t]{2}{*}{ Loop } & Count & 7 & 30 & 20 & 57 & \\
\hline & & $\begin{array}{l}\text { Expected } \\
\text { Count }\end{array}$ & 8.0 & 28.1 & 20.9 & 57.0 & $\mathrm{df}=4$ \\
\hline & \multirow[t]{2}{*}{ Whorl } & Count & 14 & 33 & 28 & 75 & \\
\hline & & $\begin{array}{l}\text { Expected } \\
\text { Count }\end{array}$ & 10.5 & 37.0 & 27.5 & 75.0 & \multirow[t]{2}{*}{$\begin{array}{c}\text { Sig }= \\
.293\end{array}$} \\
\hline \multirow{2}{*}{\multicolumn{2}{|c|}{ Total }} & Count & 21 & 74 & 55 & 150 & \\
\hline & & $\begin{array}{l}\text { Expected } \\
\text { Count }\end{array}$ & 21.0 & 74.0 & 55.0 & 150.0 & \\
\hline
\end{tabular}




\section{DISCUSSION}

Dermatoglyphics has become one of the very important topics to be understood by the human society. Day by day, its importance is felt in solving the problem of human crimes and forensic science. It has unlimited application in our problematic society especially in the law enforcing department. In spite of numerous research work in improving the study of its application like complicated finger pattern type classification (Henry's classification), total ridge count, thumbprint ridge count etc. still in-depth and extensive research to know the dermatoglyphics in details are always necessitate.

In this study, 600 thumbprint ridge patterns from 300 individuals were examined. No two prints were the same, indicating the individuality, uniqueness of fingerprints for identification and authentication. In all 600 thumbprint patterns encountered, loop was the dominant ridge pattern, followed by whorl and the least was arch. This is consistent with other studies done in Nigeria, which observed loop pattern to have the highest frequency, followed order by whorl, then arch pattern (Cummins et al., 1943; Ekanem et al., 2009; Jaja et al., 2008). Similar results were reported on the Urhopbos and Hausa by Osunwoke et al., 2008), the Ijaws by Igbigbi et al., 1999; Jaja et al., 2008, Delta State University students by Anibor et al., (2011). Studies in other parts of Africa have also reported characteristic and similar dermatoglyphic patterns like that of Nigerians though with variations in percentages (Odokuma et al., 2005, Igbigbi et al., 1995). Interestingly, our result showed that males have a higher incidence of whorls and females have a higher incidence of loops. Similar results were reported by Prateek Rastogi, et al., (2009).

Acree (1999) confirmed sex differences in fingerprint ridges using quantitative data, with females having finer details, hence, having a higher ridge count. Although, our data shows that female Nigerians in Calabar Municipality have lower thumbprint ridge count than males. These results support the idea of sexual dimorphism in human fingerprint in general and more specifically in thumbprint ridge counts. Our current study shows a trend in thumbprint ridge count regardless of the hand (i.e. left or right hand), and further emphasizes sexual dimorphism based on this thumbprint characteristics and ridge count in Nigeria. This may help in sex discrimination in forensic cases when thumbprints are of unknown sources. However, Taduran et al., (2017) warned that it should be used with caution because ridge count mean values of the thumb are much lower compared to the other fingers, which could lead to misclassification of a female as a male and vice versa.

Ridge count is the most consistent and reliable measurement for familial investigations and is an inherited metrical character (Verbor, 1970). Its quantitative nature allows for objective characterization of fingerprint, which may be helpful in identification matching. Other fingerprint characteristics where sexual dimorphism may occur, such as ridge breadths, pattern type concordances, and left-right asymmetries, should be explored further. The result of this study as well as future studies on ridge density and fingerprint ridge count maybe correlated with one another to come up with a precise sex discrimination algorithm specific for Nigerians that are based on different thumbprint and fingerprint ridge components. It may be possible to increase the accuracy of sex determination by combining finger and thumbprint techniques and other anthropometric techniques, such as Taduran's (2012) formulae from teeth dimensions.

Although, some similarities were observed in the distribution of thumbprint patterns in both sexes, this might be an indication that they share the same ancestry. The similarities are thus: The distribution of the thumbprints pattern in ascending order in all thumbprints encountered are; Arch > Whorl > Loop. These correspond with the distribution of fingerprint patters of the Africans (Onukwe, 2016). In conclusion, the result showed that in pattern distribution, males have a higher incidence of whorls and females have a higher incidence of loops.

In conclusion, the result showed that in pattern distribution, males have a higher incidence of whorls and females have a higher incidence of loops. The statistical analysis to test for the relationship of the thumbprint ridge count and the differences in sex was highly significant. This study suggests that the males have higher mean thumbprint ridge count than females and therefore thumbprint ridge count can be very instrumental in developing algorithms for sex determination. 
ACKNOWLEDGEDMENTS: The authors would like to thank all the study respondents and the research assistant for the maximum cooperation and trust in this research. We further appreciate Dr. (Mrs.) Edisua U. Iso, Dr. Asuquo Inyang (MBBS), Prof. B. O. Asuquo, Prof. (Mrs.) Ima-obong Ekanem (MBBCH), Dr. Idongesit Itaketo (MD, Ph.D) and Mr. Onuma Onyeami for their technical, moral and financial support.

COMPETING INTEREST: The authors have no competing interests.

\section{REFERENCES}

1. Adamu LH, Ojo SA, Danborno B, Adebisi SS, Taura MG. 2016. Sex prediction using ridge density and thickness among the Hausa ethnic group of Kano state, Nigeria, Australian Journal of Forensic Sciences, P.1

2. Acree MA. 1999. Is there a gender difference in fingerprint ridge density? Forensic Science International, 102:35-44.

3. Anibor E, Eboh DEO, Okumagba MT, Eteafia MO. 2011. Plamar and digital dermatoglphic patterns of the Ijaws in Delta State of Nigeria School. Application Science Reconstructive, 3 (6): 301-306.

4. Cummins H, Midlo C. 1943. Fingerprints, Palms and soles. An introduction to Dermatoglyphics. The Blankson Company, Philadelphia. 9.

5. Ekanem EP, Eluwa MA, Udoaffah GU, Ekanem TB, Akpantah AO. 2009. Digital Dermatoglyhics patterns of Annang Ethnic group in Akwa Ibom State of Nigeria. The International Journal of Biological Anthropology, 3(1).

6. Galton F. 1892. Finger Prints. London: MacMillan.

7. Igbigbi PS, Msamati BC. 1999. Palmar and digital dermatoglyphic patterns in Malawaian subjects. East Africa. Medical Journal, 76(12): 668-671.

8. Igbigbi PS, Didia BC, Agan TU, Ikpae BE. 1995. Palmar and digital dermatoglyphic pattern in two ethnic communities in Nigeria. West Africa. Journal of Anatomy, 2: 52-56.

9. Jaja BN, Igbigbi PS. 2008. Digital and Plamar Dermatoglyphics of the Ijaw of Southern Nigeria, Africa. Journal of Medical Science. 37 (1): 1-5.

10. Lakshmi PJ, Thenmozhi R. 2014. A short review of Dermatoglyphics. .Journal of Pharmaceutical Sciences \& Research, 6(4), 200-202.

11. Manish V, Suneeta A. 2008. Fingerprint Based Male-Female Classification in Proceedings of the international workshop on computational intelligence in security for information systems (CISIS'08), Genoa, Italy, 251-257.

12. Mellor CS. 1992. Dermatoglyphic Evidence of Fluctuating Asymmetry in Schizophrenia. British Journal of Psychiatry, 160:467-472

13. Mulawka M, Routledge LM. 2014. Post mortem Fingerprinting and Unidentified Human Remains. 6.

14. Odukuma EI, Igbigbi PS. 2005. Digital dermatoglyphics in students of Delta State University, Nigeria. Journal of Experimental and Clinical Anatomy, 4(1): 30-32.

15. Onukwue ET. 2016. Digital dermatoglyphic and cheiloscopic study of indigenes of Eziama Community of Abia State, Nigeria. University of Calabar.

16. Osunwoke EA, Ordu KS, Hart J, Esomonu E., TamunoKuro FB. 2008. A study on the dermatoglyphic patterns of Okrika and Ikwere ethnic groups of Nigeria. Scientist Africana, 7(2): 143147.

17. Prateek Rastogi MS, Keerthi RP 2009. A study of fingerprints in relation to gender and blood group. Journal of Indian Academic Forensic Med, 32(1), 11-14 ISSN 0971-0973.

18. Rijo JT, Arulkumaran T. 2013. Fingerprint Based Gender Classification Using 2D Discrete Wavelet Transforms and Principal Component Analysis. International Journal of Engineering Trends and Technology, 4(2).

19. Ritu K, Susmita GM. 2012. Fingerprint Based Gender Identification using Frequency Domain Analysis. International Journal of Advances in Engineering \& Technology, 2231-1963.

20. Ritu K, Susmita GM, Devan A, Bhonsle, E. 2012. A Study on Various Methods of Gender Identification Based on Fingerprints. International Journal of Emerging Technology and Advanced Engineering, 2250-2459, 2(4). 
21. Taduran RJ. 2012. Sex determination from maxillary and mandibular canines of the Filipino population. In: Townsend G, Kanazawa E, Takayama $H$, editors. New Directions in Dental Anthropology: Paradigms, Methodologies and Outcomes. Adelaide: University of Adelaide Press, 8293.

22. Taduran RJ, Ryu O, Ishimura, B. Margarita M, Brook A, Grant CT. 2017. Sex variation in fingerprint ridge counts in Filipinos. European Journal of Forensic Sciences, 4(3). DOI 10.5455/ejfs.239855.

23. Verbov, J. 1970. Clinical Significance and genetics of epidermal ridges - a review of dermatoglyphics. The Journal of investigative dermatology, 54: 261-71. 